\section{Influence of Plant Age on Nutrient Absorption for Marigold Seedlings}

\author{
Deborah A. Tolman ${ }^{1}$, Alexander X. Niemiera ${ }^{2}$, and \\ Robert D. Wright ${ }^{3}$ \\ Department of Horticulture, Virginia Polytechnic and State University, \\ Blacksburg, VA 24061
}

Additional index words. bedding plants, nutrition, fertilizers, ornamental plants, nutrient uptake, Tagetes erecta, container-grown

Abstract. Seedlings of 30-, 35, 40-, -45, and 50-day-old marigold (Tagetes erecta Big. 'Inca Gold') in 500-ml plastic pots containing a 1 peat : 1 perlite (v/v) medium were treated with several fertilizer levels $\left(\mathrm{N}\right.$ at 20, 50, 80, and $\left.110 \mathrm{mg}^{-1 i t e r}{ }^{-1}\right)$; solution nutrient levels in the medium were determined 6 hours later. Older/larger containergrown plants absorbed more $\mathbf{N}, \mathbf{P}$, and $\mathrm{K}$ from the medium solution than younger/ smaller plants. Also, older plants ( $>40$ days) absorbed at least $88 \%$ of the solution $N$ regardless of $\mathbf{N}$ treatment. Nitrogen absorption, regardless of plant age, increased as $\mathbf{N}$ application rates increased. The latter result implies that even though total $\mathbf{N}$ absorption increases with plant age/size, nutrient levels in the medium solution for optimal growth and nutrient uptake may be similar regardless of plant size.

A plant's nutrient requirement increases with age/size during periods of exponential growth. Therefore, the supply and uptake of nutrients must be increased to maintain maximum plant growth. This well-established concept has been demonstrated with plants growing in recirculating solution culture systems (Edwards and Barber, 1976a, 1976b; Edwards and Asher, 1974: Ingestad, 1979, 1981; Ingestad and Kahr, 1985).

Greenhouse crops are commonly fertilized at one application concentration throughout most of the production cycle, without regard to plant size or age. For example, floriculture crops (Mastalerz, 1977) and bedding plants (Mastalerz and Holcomb, 1985) are usually fertilized two to three times a week at 150 to $200 \mathrm{mg} \mathrm{N} / \mathrm{liter}$ in the irrigation water. These recommendations are made without mention of plant age in relation to nutrient requirements. Little attention has been given to identifying nutrient requirements of container-grown plants as related to plant age or stage of development. Such research could determine optimal fertilizer application rates based on plant requirements for nutrients. The purpose of this research was to investigate the influence of plant age/size on nu-

Rcceivcd for publicarion 7 Dee. 1988. Research was supporrcd in part by rhe Virginia Nurserymen's Association. The cost of publishing rhis paper was dcfraycd in part by rhc payment of page charges. Under postal regulations, rhis paper therefore musr bc hcrcby marked udvenisemenr solely ( 0 indicate this fact.

IGraduarc Student.

:Assistant Professor.

"Professor. trient removal from a container medium solution supplied with different $\mathrm{N}$ levels.

'Inca Gold' marigold seeds were germinated under intermittent mist at 5-day intervals starting on 8 Sept. 1985 and ending on 28 Sept. Seeds were sown directly in 500$\mathrm{ml}$ plastic pots containing a medium of 1 peat : 1 perlite $(\mathrm{v} / \mathrm{v})$ amended with $1 \mathrm{~kg}$ Micromax $/ \mathrm{m}^{3}$ (Sierra Chemical Co., Milpitas, Calif.) and $6 \mathrm{~kg}$ dolomitic lime $/ \mathrm{m}^{3}$. Germination occurred in 3 to 4 days, after which plants were grown in a greenhouse vented at $24 \mathrm{C}$ during the day and the night minimum was maintained at $18 \mathrm{C}$. Plants were placed on raised benches and arranged in a randomized complete-block design with 80 plants per age group in each of five blocks.

After emergence, plants were irrigated with $200 \mathrm{ml}$ of a nutrient solution containing $\left(\mathrm{mg} \cdot l i t \mathrm{r}^{-1}\right.$ ) $200 \mathrm{~N}$ from $\mathrm{NH}_{4} \mathrm{NO}_{3}, 25 \mathrm{P}$ from $\mathrm{H}_{3} \mathrm{PO}_{4}$ and $150 \mathrm{~K}$ from $\mathrm{K}_{2} \mathrm{SO}_{4}$. After every two nutrient solution irrigations, plants were irrigated with $200 \mathrm{ml}$ of tap water to prevent excessive salt accumulation in the medium. Frequency of irrigation depended on plant need for water.

On 28 Oct. 1985, there were five plant ages (30, 35, 40, 45, and 50 days from seedling emergence) with dry weights of $0.3,0.8$, $1.1,4.2$, and $7.8 \mathrm{~g}$, respectively. At 2200 HR 10 plants of each age were irrigated with 1 liter of either $20,50,80$, or $110 \mathrm{mg} \mathrm{N} /$ liter (from $\mathrm{NH}_{4} \mathrm{NO}_{3}$ ) to equilibrate the medium solution with the applied solution. This treatment was repeated at $0700 \mathrm{HR}$ on 29 Oct. One hour later, medium solutions were extracted from five pots per $\mathrm{N}$ treatment per age using the pour-through technique (Yeager et al., 1983) in which $45 \mathrm{ml}$ of distilled water was applied to the surface of the medium and the leachate collected. Medium solutions were extracted again on a different group of five plants per $\mathrm{N}$ level per age at $1400 \mathrm{HR}$. This testing date was designated pour-through (PT) 1. Medium solution extraction at 0800 and $1400 \mathrm{HR}$ was repeated 10 days later (PT 2) using the same group of plants. During this 10-day interval, plants of each group were fertilized daily with the $20,50,80$, and 110 $\mathrm{mg} \mathrm{N} /$ liter treatments noted earlier.

Uniform moisture levels of all treatments were maintained between 0800 and 1400 HR by wrapping containers in plastic film to minimize water lost by evaporation. Ever-y 15 to $30 \mathrm{~min}$, containers were weighed and any water lost via transpiration was replaced with distilled water. Thus, moisture levels were maintained at container capacity and at the same levels each time nutrient extractions were made. Leachates were analyzed for $\mathrm{NH}_{4}-\mathrm{N}$ and $\mathrm{NO}_{3}-\mathrm{N}$ using ion-selective electrodes, for $\mathrm{P}$ using a calorimetric technique (Watanabe and Olsen, 1965), and for $\mathrm{K}$ by atomic absorption spectrophotometry.

Medium solution $\mathrm{N}, \mathrm{P}$, and $\mathrm{K}$ concentrations measured at 0800 and $1400 \mathrm{HR}$ were multiplied by the volume of medium solution $(200 \mathrm{ml})$ to express the amount of nutrient removed from the medium solution on an absolute basis. Volume of medium solution was calculated as the difference between wet weight of a saturated medium sample and an oven-dried medium sample. Regression analysis was performed using Proc Stepwise in SAS (SAS Institute, 1985).

Controls were established to determine if the medium either adsorbed or desorbed nutrients during the 6-hr test. Two days before PT 1, two plants per block per $\mathrm{N}$ treatment for the 30- and 50-day-old plants were cut at medium level. On 29 Oct. these containers were subjected to the same $\mathrm{N}$ treatments and PT procedure as described previously.

Plant nutrient absorption was quantified by the difference in initial and final medium solution nutrient values for the 6-hr test. Initial solution extraction occurred $1 \mathrm{hr}$ after nutrient treatment application. Initial solution $\mathrm{N}, \mathrm{P}$, and $\mathrm{K}$ concentrations (Table 1) were less than those applied, with the difference increasing with plant age/size. For example, solution $\mathrm{N}$ concentrations for 30day-old plants were $72 \%, 79 \%, 80 \%$. and $92 \%$ of the applied $20,50,80,110 \mathrm{mg} \cdot$ liter $^{-1}$ values, respectively, whereas concentrations for the 50-day-old plants were 33\%, 45\%, $55 \%$, and $62 \%$, respectively. This trend indicates that older plants were absorbing more $\mathrm{N}$ before treatment applications, resulting in different medium solution $\mathrm{N}$ concentrations following treatment.

Nitrogen absorption increased with in- 
Table 1. Initial medium solution $\mathrm{N}, \mathrm{P}, \mathrm{K}$ concentrations at different $\mathrm{N}$ levels and for different age plants (PT 1).

\begin{tabular}{|c|c|c|c|c|c|c|c|c|c|c|c|c|c|c|c|}
\hline \multirow{4}{*}{$\begin{array}{l}\mathrm{N} \\
\text { treatment } \\
\text { (mg-liter-1) }\end{array}$} & \multicolumn{15}{|c|}{ Initial conen (mg $\left.\cdot \operatorname{liter}^{-1}\right)$} \\
\hline & \multicolumn{15}{|c|}{ Age of plant (days) } \\
\hline & \multicolumn{3}{|c|}{30} & \multicolumn{3}{|c|}{35} & \multicolumn{3}{|c|}{40} & \multicolumn{3}{|c|}{45} & \multicolumn{3}{|c|}{50} \\
\hline & $\mathrm{N}$ & $P$ & $\mathrm{~K}$ & $N$ & $\mathrm{P}$ & $\mathrm{K}$ & $N$ & $P$ & $\mathrm{~K}$ & $N$ & $\mathrm{P}$ & $\mathrm{K}$ & N & $\mathrm{P}$ & $\mathrm{K}$ \\
\hline 20 & 13 & 17 & 116 & 13 & 16 & 104 & 11 & 16 & 106 & 8 & 14 & 83 & 7 & 15 & 90 \\
\hline 50 & 39 & 16 & 103 & 33 & 5 & 72 & 27 & 15 & 94 & 23 & 12 & 76 & 23 & 13 & 53 \\
\hline 80 & 64 & 15 & 101 & 58 & 4 & 38 & 50 & 15 & 86 & 42 & 13 & 80 & 44 & 14 & 82 \\
\hline 110 & 102 & 16 & 115 & 100 & 5 & 26 & 70 & 14 & 100 & 76 & 14 & 91 & 68 & 13 & 97 \\
\hline
\end{tabular}

Table 2. Amount and percent of total $\mathrm{N}$ absorbed from medium solution (PT 1) at several $\mathrm{N}$ lcvcls and for plants of various ages.

\begin{tabular}{|c|c|c|c|c|c|c|c|c|c|c|c|c|c|c|}
\hline \multirow{4}{*}{$\begin{array}{l}\mathrm{N} \\
\text { treatment } \\
\left(\mathrm{mg} \cdot \text { liter }^{-1}\right)\end{array}$} & \multicolumn{10}{|c|}{$\mathrm{N}$ absorbed } & & & & \\
\hline & \multicolumn{10}{|c|}{ Age of plants (days) } & \multicolumn{4}{|c|}{ Statistics } \\
\hline & \multicolumn{2}{|c|}{30} & \multicolumn{2}{|c|}{35} & \multicolumn{2}{|c|}{40} & \multicolumn{2}{|c|}{45} & \multicolumn{2}{|c|}{50} & \multicolumn{2}{|r|}{$\mathrm{mg}$} & \multicolumn{2}{|r|}{$\%$} \\
\hline & $\mathrm{mg}$ & $\%$ & $\mathrm{mg}$ & $\%$ & $\mathrm{mg}$ & $\%$ & $\mathrm{mg}$ & $\%$ & $\mathrm{mg}$ & $\%$ & Lincar & Quadratic & Lincar & Quadratic \\
\hline 20 & 0.9 & 32.1 & 2.3 & 90.6 & 2.0 & 89.9 & 1.4 & 89.4 & 1.2 & 88.4 & $\cdots$ & $\cdots$ & $\cdots$ & $\cdots$ \\
\hline 50 & 1.8 & 20.6 & 4.6 & 72.3 & 4.6 & 87.8 & 4.3 & 95.3 & 4.3 & 95.6 & $\cdots$ & $\cdots$ & $* *$ & $* * *$ \\
\hline 80 & 2.6 & 19.6 & 4.4 & 37.7 & 6.1 & 60.9 & 8.0 & 94.9 & 8.6 & 98.0 & $\cdots *$ & NS & $\cdots$ & NS \\
\hline 110 & 3.0 & 14.7 & 5.2 & 26.1 & 5.7 & 34.8 & 13.6 & 88.6 & 13.3 & 97.4 & NSS & $\cdots$ & NS & $\cdots *$ \\
\hline \multicolumn{15}{|l|}{ Slatistics ${ }^{2}$} \\
\hline Linear & $*$ & NS & 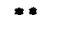 & $\cdots$ & - & NS & NS & $\approx$ & $\cdots *$ & $* *$ & & & & \\
\hline Quadratic & NS & NS & NS & NS & * & $* \cdots$ & $\cdots *$ & $\cdots$ & NS & $\cdots$ & & & & \\
\hline
\end{tabular}

${ }^{\mathrm{z}}$ Regression performed on arcsin [square root (proportion)].

NS,$* * * * * *$ Nonsignificant or significant at $P=0.05,0.01$, or 0.001 , respectively.

Table 3. Amounts of $\mathrm{P}$ and $\mathrm{K}$ absorbed by plants of various ages.

\begin{tabular}{lcc}
\hline \hline & \multicolumn{2}{c}{$\begin{array}{c}\text { Absorbed } \\
\text { (mg) }\end{array}$} \\
\cline { 2 - 3 } Age & $\mathrm{P}$ & $\mathrm{K}$ \\
\hline 30 & 0.38 & 0.61 \\
35 & 0.41 & 3.20 \\
40 & 0.92 & 3.60 \\
45 & 1.70 & 10.00 \\
50 & 2.30 & 12.80 \\
Lincar & $\cdots$ & $\mathrm{NS}$ \\
Quadratic & $\ldots$ & $\cdots$ \\
\hline Ns ${ }^{*}, * *, * * * *$ & Nonsignificant or significant at $P=0.05$ \\
or 0.001, respectively. &
\end{tabular}

creasing $\mathrm{N}$ treatment and plant age (Table 2). An exception to this was that $\mathrm{N}$ absorption did not increase beyond age 35 days for the 20 and $50 \mathrm{mg} \cdot$ liter $^{-1}$ treatments. Also. older plants ( $>40$ days) adsorbed at least $88 \%$ of the solution $\mathrm{N}$ within $6 \mathrm{hr}$ regardless of $\mathrm{N}$ treatment compared to $32 \%$ or less for 30 day-old plants.

Phosphorus and $\mathrm{K}$ absorption were not influenced by $\mathrm{N}$ treatment (data not shown). Amounts of $\mathrm{P}$ and $\mathrm{K}$ absorbed during the 6$\mathrm{hr}$ test, averaged over all $\mathrm{N}$ levels, increased as plant age/size increased (Table 3 ).

Data from controls (containers from which plant shoots had been excised) demonstrated a consistent increase of $0.9 \mathrm{mg} \mathrm{NO}-\mathrm{N}$ and a decrease of $0.6 \mathrm{mg} \mathrm{NH}_{4}-\mathrm{N}$ across all $\mathrm{N}$ treatments for both age groups (data not shown). Thus, $\mathrm{N}$ sorbtion or transformations did nor interfere with interpretations for $\mathrm{N}$ removal data during the 6-hr period. The increase in $\mathrm{NO}_{3}^{-}$accompanied by a decrease in $\mathrm{NH}_{4}^{+}$; could be the result of nitrification, which has been shown to occur in organic substrates (Niemiera and Wright, 1986).

Results show that older/larger containergrown marigold plants absorbed more $\mathrm{N}, \mathrm{P}$, and $\mathrm{K}$ from the medium solution than younger/ smaller plants. Also, older plants (>40 days) absorbed at least $88 \%$ of the solution $\mathrm{N}$ regardless of $\mathrm{N}$ treatment. Of particular interest is that $\mathrm{N}$ absorption, regardless of plant age, increased as $\mathrm{N}$ application rates increased. The fact that a 30-day-old plant absorbed one-third as much $\mathrm{N}$ when treated with $20 \mathrm{mg} \cdot \mathrm{liter}^{-1}$ as when treated with 110 $\mathrm{mg} \cdot \mathrm{liter}^{-1}$ implies that the driving force for nutrient uptake is the nutrient concentration in the medium solution. This is a well-documented plant nutrition principle (Mengel and Kirkby, 1987). The increased nutrient demand and absorption of 50-day-old plants compared to 30-day-old plants, regardless of $\mathrm{N}$ level, may be attributed to the larger root system of the older plant accessing a greater volume of the container medium. Thus, for optimal absorption and growth, the less extensive root system of a small plant would require a nutrient solution concentration similar to that for a large plant.

The fact that $\mathrm{N}$ absorption did not increase beyond age 35 days at 20 and $50 \mathrm{mg} \cdot$ liter $^{-1}$ might be related IO the difference in initial $\mathrm{N}$ concentration following treatments (Table 1 ). There was only $\approx 50 \%$ of the available $\mathrm{N}$ for older plants vs. young plants and, therefore, $\mathrm{N}$ supply became limiting during the 6-hr experimental period to roots of older plants as a result of a greater demand and limited supply from the medium solution.

Young plants supplied with relatively high nutrient concentrations absorbed a small fraction $(<33 \%)$ of the applied nutrients. In a nursery situation these unused nutrients would have been leached from containers and might have polluted the environment. Further research is needed to investigate the relationship between plant growth and development and medium solution nutrient concentrations that result in maximum growth. Considerations in this research should be given to the influence of container size, medium characteristics, and nutrient application and irrigation methods.

\section{Literature Cited}

Edwards, D.G. and C.J. Asher. 1974. The significance of solution flow rate in flowing culture experiments. Plant and Soil 41:161-175.

Edwards, D.C. and S.A. Barber. 1976a. Nitrogen uptake characterization of corn roots at low $\mathrm{N}$ concentration as influenced by plant age. Agron. J. $68: 17-19$

Edwards, D.G. and S.A. Barber. 1976b. Nitrogen flux into corn roots as influenced by shoot requirement. Agron. J. 66:471-473.

Ingestad, T. 1979. Nitrogen stress in birch secdlings. 2. N. K, P, Ca and Mg nutrition. Physiol. Plant. 45:149-157.

Inges:ad. T. 1981. Nutrition and growth of birch and grey alder seedlings in low conductivity solutions and at varied relative rate of nutrient addition. Physiol. Plant. 52:454-466.

Ingestad. T. and M. Kahr. 1985. Nutrition and growth of coniferous seedlings at varied relative nitrogen addition rate. Physiol. Plant. 65:109116.

Mastalerz, J.W. 1977. The greenhouse cnvironment. Wiley, New York.

Mastalerz, J.W. and E.J. Holcomb. 1985. Bedding plants Ill; 3rd ed. Pa. Flower Growers, University Park.

Mcngel. K. and E.A. Kirkby. 1987. Principles of plant nutrition. Intl. Potash Inst. Bern, Switzerland.

Niemiera, A.X. and R.D. Wright. 1986. Influence of nitrification on the medium solution and growth of azalea, holly, and juniper in a pine bark medium. J. Amer. Soc. Hort. Sci. 111:708712.

SAS Institure, Inc. 1985. SAS user's guide. version 5. SAS Institure, Inc., Gary, N.C.

Watanabe, F.S. and S.R. Olsen. 1965. Test of an ascorbic acid method for determining phosphorus in water and $\mathrm{NaHCO}_{3}$ extracts from soil. Soil Sci. Soc. Amer. Proc. 29:677-678.

Yeager, T.H.. R.D. Wright, and S.J. Donohue. 1983. Comparison of pour-through and saturated pine bark extract $\mathrm{N}, \mathrm{P}, \mathrm{K}$ and $\mathrm{pH}$ levels. J. Amer. Soc. Hort. Sci. 108:112-114. 